Sains Malaysiana 46(2)(2017): 181-188

http://dx.doi.org/10.17576/jsm-2017-4602-01

\title{
Peak Friction Angle Estimation from Joint Roughness Coefficient of Discontinuities of Limestone in Peninsular Malaysia
}

(Anggaran Sudut Geseran Puncak daripada Pekali Kekasaran Kekar Ketakselanjaran Batu Kapur di Semenanjung Malaysia)

\author{
Ailie Sofyiana Serasa, GoH Thian LaI*, Abdul GHani RaFeK, AZimah Hussin, \\ LEE KHAI ERN \& TUAN RUSLI MOHAMED
}

\begin{abstract}
The peak friction angle $\left(\phi_{\text {peak }}\right)$ roughness of discontinuity surfaces is a value that is fundamental to the understanding of shear strength of geological discontinuities, considering its importance in determining the mechanical properties of the discontinuity surface. It is however, both time and cost demanding to determine the peak friction angle as it requires an extensive series of laboratory tests. This paper presents an approach in the form of an experimentally determined polynomial equation to estimate peak friction angle of limestone discontinuity surfaces by measuring the Joint Roughness Coefficient (JRC) values in a field survey study, and applying the fore mentioned empirical correlation. A total of 1967 tilt tests and JRC measurements were conducted in the laboratory to determine the peak friction angles of rough limestone discontinuity surfaces. The experimental results were analyzed and correlated to establish a polynomial equation of $\phi_{\text {peak }}=-0.0635 \mathrm{JRC} C^{2}+3.95 \mathrm{JRC}+25.2$ with coefficient of determination $(R 2)$ of 0.99 . The laboratory results were also compared with theoretical results calculated from Barton's linear equation. The results shown that estimation of peak friction angles were more accurate using the newly proposed polynomial equation since the percentage differences between measured and calculated peak friction angles is less than 6\% compared to estimation from Barton's linear equation where the percentage of differences is less than 11\%. The proposed correlation offers a practical method for estimation of peak friction angles of discontinuity surfaces of limestone from measurement of JRC in the field.
\end{abstract}

Keywords: Discontinuity surface roughness; empirical correlation; joint roughness coefficient (JRC); limestone; peak friction angle

\section{ABSTRAK}

Sudut geseran puncak (фpeak) kekasaran permukaan ketakselanjaran adalah nilai asasi kepada pemahaman tentangkekuatan ricih ketakselanjaran geologi, memandangkan kepentingannya dalam menentukan sifat mekanik permukaan ketakselanjaran. Walau bagaimanapun, ia memerlukan masa dan kos yang tinggi untuk menentukan sudut geseran puncak kerana ia memerlukan satu siri ujian makmal yang menyeluruh. Kertas ini membentangkan suatu pendekatan dalam bentuk persamaan polinomial yang dijalankan secara makmal untuk menganggar sudut geseran puncak permukaan ketakselanjaran batu kapur dengan mengukur Pekali Kekasaran Kekar (JRC) dalam kajian survei lapangan dan menggunakan empirikal korelasi yang disebutkan sebelum ini. Sejumlah 1967 ujian kemiringan dan pengukuran JRC telah dijalankan di dalam makmal untuk menentukan sudut geseran puncak permukaan kasar ketakselanjaran batu kapur. Keputusan ujian telah dianalisis dan dikorelasi untuk mewujudkan persamaan polinomial ppeak $=-0.0635 J R C 2+3.95 J R C+25.2$ dengan pekali penentuan (R2) sebanyak 0.99. Keputusan makmal juga dibandingkan dengan keputusan secara teori yang dikira daripada persamaan linear Barton. Hasil menunjukkan bahawa anggaran sudut geseran puncak adalah lebih tepat dengan menggunakan persamaan polinomial baru yang dicadangkan memandangkan perbezaan peratusan antara sudut geseran puncak yang diukur dengan yang dikira adalah kurang daripada 6\% berbanding dengan anggaran daripada persamaan linear Barton dan peratusan perbezaan adalah kurang daripada $11 \%$. Korelasi yang dicadangkan memberikan suatu kaedah praktikal untuk anggaran puncak sudut geseran permukaan ketakselanjaran batu kapur daripada pengukuran JRC dalam lapangan.

Kata kunci: Batu kapur; kekasaran ketakselanjaran permukaan; korelasi empirikal; pekali kekasaran kekar (JRC); sudut geseran puncak

\section{INTRODUCTION}

Rock slope stability analyses have to be considered as a compulsory evaluation during excavation projects in civil, mining and geotechnical industry. Difficulties in determination of stability have brought about the emergence of fundamental studies on peak shear strength of rough discontinuity surfaces since shear strength is a pivotal factor causing failures. Determination of peak 
friction angle provides an important frictional property in describing the ability of a discontinuity plane to resist shear stress. The literature study showed that less research were conducted on the peak shear strength of discontinuity surfaces of limestone. Local researchers focused more on rock mass classification (Norbert et al. 2016), landslide study (Norbert et al. 2015a, 2014, 2013), rock fall study (Norbert et al. 2015b) and prediction of uniaxial compressive strength (Goh et al. 2016, 2015a, 2015b, 2014b). However, Ghani Rafek et al. (2012, 2011) and Goh et al. (2012, 2014a) established a polynomial relationship between JRC with peak friction angles for schist and granite.

Under low normal stress, the existing Mohr-Coulomb failure criterion (1773) suggests that the shear strength of rock material varies with the normal stress, friction angle and cohesion which can be described by the following equation:

$$
\tau=c+\sigma_{\mathrm{n}} \tan \phi,
$$

where $\tau$ is the shear strength of rock material; $c$ is the cohesion; $\sigma_{n}$ is the normal stress on failure plane; and $\phi$ is the internal friction angle.

A study by Patton (1966) concluded that the shear strength of discontinuity surfaces are strongly influenced by the surface roughness of discontinuity planes. In practice, the best way to characterize surface roughness is by direct measurement in the field. Fecker and Rengers (1971) characterized the surface roughness of discontinuities by using plates of different sizes attached to a geological compass to measure deviations from the mean plane. Different plate sizes allow roughness to be recorded on various scales in determining the potential sliding direction.

This is demonstrated by Patton (1966) in laboratory experiment on 'saw-tooth' rock samples. Dilation of the rock samples were due to effects of the surface sliding along the inclined surfaces. Estimation of peak friction angle as a function of normal stress can be described as:

$$
\tau=\sigma_{\mathrm{n}} \tan \left(\phi_{\mathrm{b}}+i\right)
$$

where $\tau$ is the shear strength of the discontinuity surface; $\sigma_{n}$ is the normal stress on failure plane; $\phi_{\mathrm{b}}$ is the basic friction angle of the surface; and $i$ is the angle of the saw-tooth face. The value of $\left(\phi_{\mathrm{b}}+i\right)$ represents the peak friction angle of the discontinuity surface.

Barton (1973) suggested a relationship to estimate the peak friction angle by introducing the surface roughness parameter and the joint wall strength as a function of the normal stress. Barton rewrote the linear equation as:

$$
\tau=\sigma_{\mathrm{n}} \tan \left[\left(\phi_{\mathrm{b}}+\mathrm{JRC} \log _{10}()\right],\right.
$$

where $\tau$ is the shear strength of the discontinuity surface; $\mathrm{JCS} / \sigma_{\mathrm{n}}$ is the normal stress on failure plane; $\phi_{\mathrm{b}}$ is the basic friction angle of the surface; JRC is the joint roughness coefficient of the discontinuity surface; and JCS is the uniaxial compressive strength of the rock material. The value of $\left(\phi_{\mathrm{b}}+\mathrm{JRC} \log _{10}\left(\mathrm{JCS} / \sigma_{\mathrm{n}}\right)\right.$ represents the peak friction angle of discontinuity surface roughness.

Ghani Rafek et al. (2012) and Goh et al. (2014a, 2012) have established a polynomial equation to estimate peak friction angles from JRC of discontinuities for fresh and slightly weathered schist and granite samples in Malaysia by using tilt test method (Ghani et al. 2011). This method is simple, inexpensive and it allows for direct measurement of the peak friction angle in the laboratory.

Hence, the purpose of this study was to establish the peak friction angle equation for limestone in Kinta Valley, Gunung Keriang and Gua Damai area. The findings of this study is expected to be useful by presenting a comparable range of peak friction angles with regard to the JRC values of limestone in Kinta Valley, Gunung Keriang and Gua Damai and to propose a simple and time-saving method for estimation of peak friction angle.

\section{GEOLOGY OF STUDY AREA}

The study area in Perak is within the vicinity of the Kinta Valley where it is situated in the central part of the state covering Gopeng and Ipoh district. Foo (1990) reported that the age of Kinta limestone ranges from the Silurian to Permian with the deposition of the clastic sediment in a relatively deep marine setting followed by the deposition of limestone following the progressive shallowing of the sea.

The study area in Kedah is in the city of Alor Setar. Gunung Keriang is the southern most exposure of the Chuping limestone Formation and was previously classified as Kodiang Formation. It is not until early 1960s that all limestone hills in the Kodiang Formation that are deposited in the Permian were reclassified as Chuping Formation (Jones 1976). The age of Gunung Keriang limestone ranges from Smithian to Ladinian-Carnian and the age of Chuping limestone ranges from Lower Permian to Middle and Upper Triassic. The Kodiang limestone was deposited during the Permian to the Triassic age.

The study area in Selangor is within the Gombak district, $13 \mathrm{~km}$ north of Kuala Lumpur. Gua Damai is part of the Palaeozoic Formations of Selangor and Kuala Lumpur. The geology of the area consists of sedimentary rocks ranging in age from Middle-Upper Silurian to Mesozoic or Younger overlying the older Hawthornden Formation and the Kuala Lumpur Limestone Formation (Gobbett 1964). Figure 1 shows the location of study areas.

\section{MATERIALS AND METHODS}

\section{SAMPLE DESCRIPTION}

Limestone samples collected from Kinta Valley and Gua Damai are pale yellow in color, while samples from Gunung Keriang are dark grey in color. From hand sample, the limestone are fresh (grade I) and are composed of medium to fine grain size. 


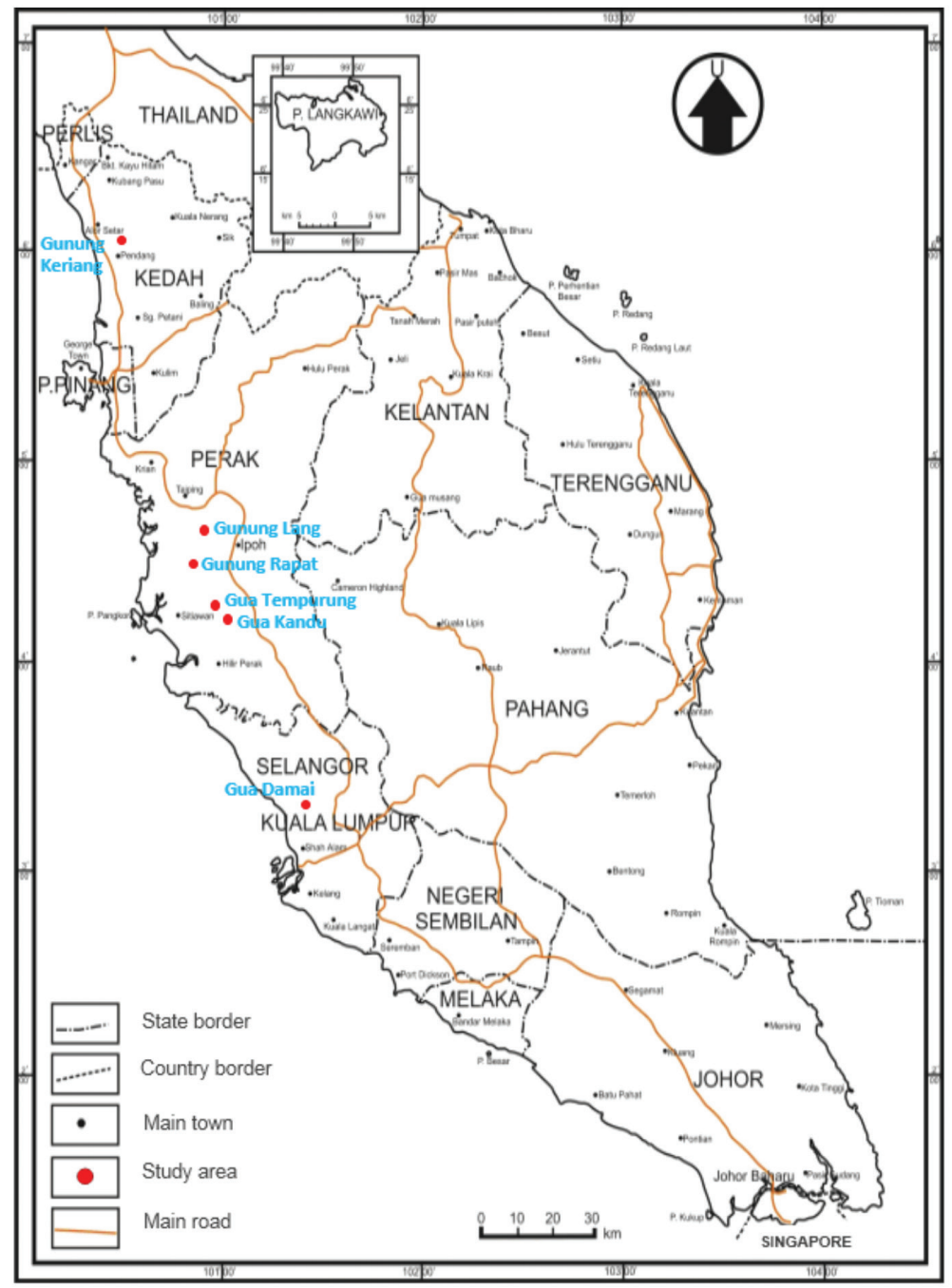

FIGURE 1. Location of study area

\section{SAMPLE PREPARATION}

Rock samples constituting two parts that contain natural discontinuity planes were collected by using hand tools such as geological hammers from different study areas and were carefully separated into upper and lower block along the natural discontinuity planes (Figure 2). Rock samples

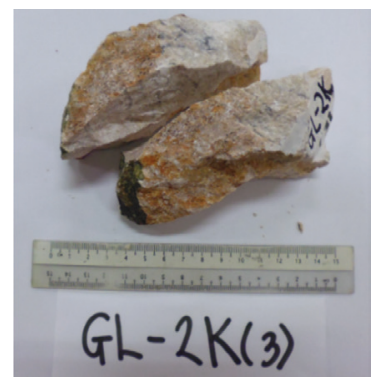

FIGURE 2. Rock samples constituting two parts that contain natural discontinuity planes were carefully separated into upper and lower block along the natural discontinuity planes by using geological hammers and were prepared in an elongated shape

to minimize the possibility of toppling were prepared with an elongated shape to minimize the possibility of toppling.

\section{JOINT ROUGHNESS COEFFICIENT (JRC) MEASUREMENT}

The roughness of the discontinuity surfaces were measured using a Barton comb to reproduce the true roughness profiles (Figure 3). The obtained profiles were compared to the corresponding standard profiles of Joint Roughness Coefficient (JRC) suggested by Barton and Choubey (1977)

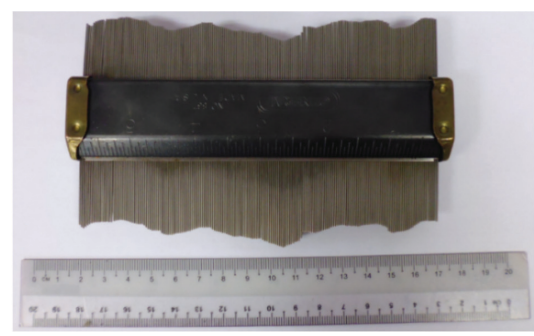

FIGURE 3. Standard $15 \mathrm{~cm}$ Barton comb used to reproduce the true roughness profiles of discontinuity surfaces 
as shown in Figure 4. The surface roughness of these planes was measured in four different directions that correspond to the direction of sliding.

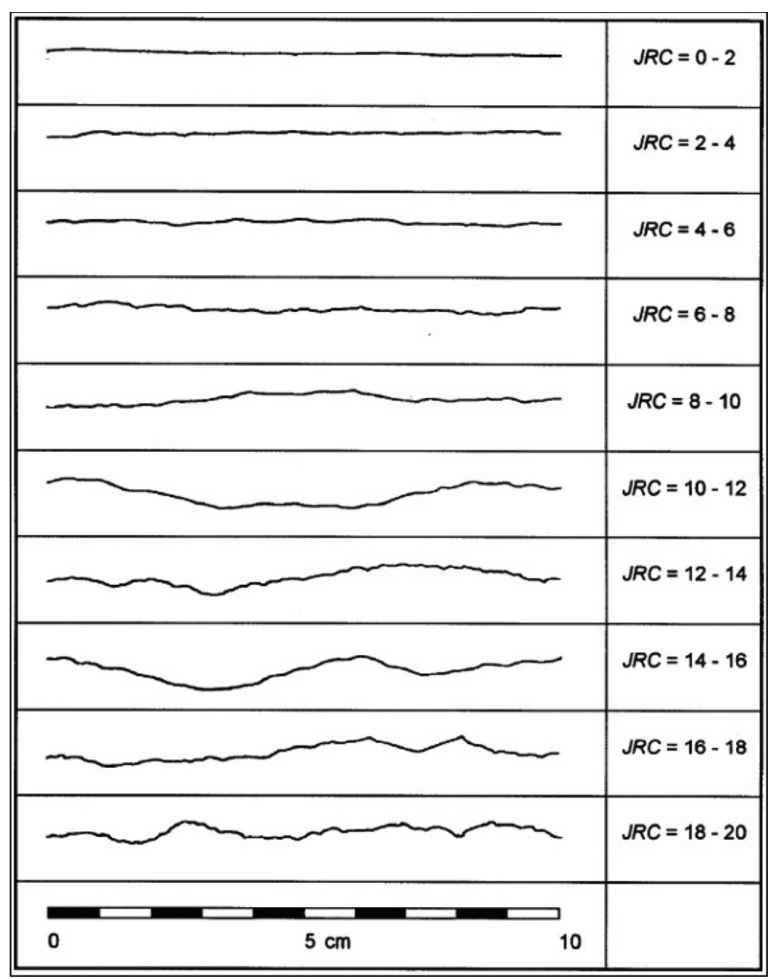

FIGURE 4. Joint Roughness Coefficient (JRC) for different surface roughness profiles (Barton \& Choubey 1977)

\section{TILT TEST}

Peak friction angles $\left(\phi_{\text {peak }}\right)$ were measured by using a self-fabricated tilt testing apparatus according to Priest (1993) suggestion (Figure 5). Rock samples that contained upper and lower rock blocks were positioned on the plane and were slowly inclined from the horizontal position until sliding between the planes occurred. The angle of inclination which represents the peak friction angle was measured with a clinometer. The tilt tests were repeated five times for each direction to reduce possible errors during measurements. The tilt angles of these blocks were

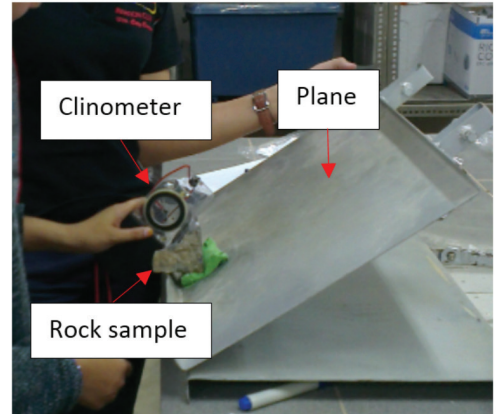

FIGURE 5. A self-fabricated tilt testing apparatus, modeled after Priest (1993) used for measurement of peak friction angle, $\phi_{\text {peak }}$

measured in different directions due to variety of the JRC values according to the direction of sliding.

\section{RESULTS AND DISCUSSION}

A total of 1967 tilt tests were conducted on grade I limestone samples from the six different locations. The Joint Roughness Coefficient (JRC) for all the natural discontinuity planes that were subjected to tilt test were also determined. The results of minimum, maximum, mean, median, standard deviation and skewness of testing were summarized in Table 1. The results of testing were analyzed at $95 \%$ confidence level using the statistical software package IBM SPSS Statistics Version 16.

The boxplots of tilt angles that corresponds to the value of discontinuity surface roughness are shown in Figure 6(a). Negative skewness implies that more test results have higher value of peak friction angle compared to the mean value, while positive skewness implies that more test results have lower value of peak friction angle compared to the mean value. A polynomial approximation, $\phi_{\text {peak }}=-0.0635 \mathrm{JRC}^{2}+$ $3.95 \mathrm{JRC}+25.2$ with a coefficient of determination $\left(\mathrm{R}^{2}\right)$ of 0.99 had been established from the empirical correlation between the experimental and the theoretical results as shown in Figure 6(b). The value of JRC were taken as the midpoint values of the respective JRC ranges. It can be seen that there is a strong correlation between the value of JRC and peak friction angle measured by conducting tilt test, seeing that the coefficient of correlation $\mathrm{R}^{2}$ are 0.99 .

TABLE 1. Summary of the statistical results of tilt testing with the respective JRC values

\begin{tabular}{cccccccc}
\hline JRC Midpoint & No. of Tests & $\operatorname{Min}\left({ }^{\circ}\right)$ & $\operatorname{Max}\left({ }^{\circ}\right)$ & Mean $\left(^{\circ}\right)$ & Median $\left(^{\circ}\right)$ & Standard deviation $\left(^{\circ}\right)$ & Skewness \\
\hline 1 & 665 & 18 & 36 & $30.1 \pm 0.1$ & 30 & 3.10 & Normal \\
3 & 200 & 26 & 42 & $34.4 \pm 0.2$ & 34 & 2.69 & Normal \\
5 & 35 & 32 & 52 & $43.1 \pm 0.9$ & 42 & 5.25 & Positive \\
7 & 90 & 32 & 68 & $50.5 \pm 0.7$ & 50 & 6.89 & Normal \\
9 & 285 & 30 & 82 & $57.6 \pm 0.5$ & 58 & 8.70 & Normal \\
11 & 220 & 46 & 80 & $61.2 \pm 0.5$ & 60 & 7.63 & Positive \\
13 & 170 & 50 & 86 & $65.1 \pm 0.6$ & 64 & 7.70 & Positive \\
15 & 105 & 42 & 82 & $68.8 \pm 0.9$ & 70 & 8.72 & Negative \\
17 & 72 & 58 & 88 & $73.5 \pm 1.1$ & 72 & 9.71 & Positive \\
19 & 125 & 60 & 88 & $78.4 \pm 0.5$ & 80 & 6.00 & Negative \\
\hline
\end{tabular}


(a) Boxplot of tilt angles that corresponds to the JRC of discontinuities surface

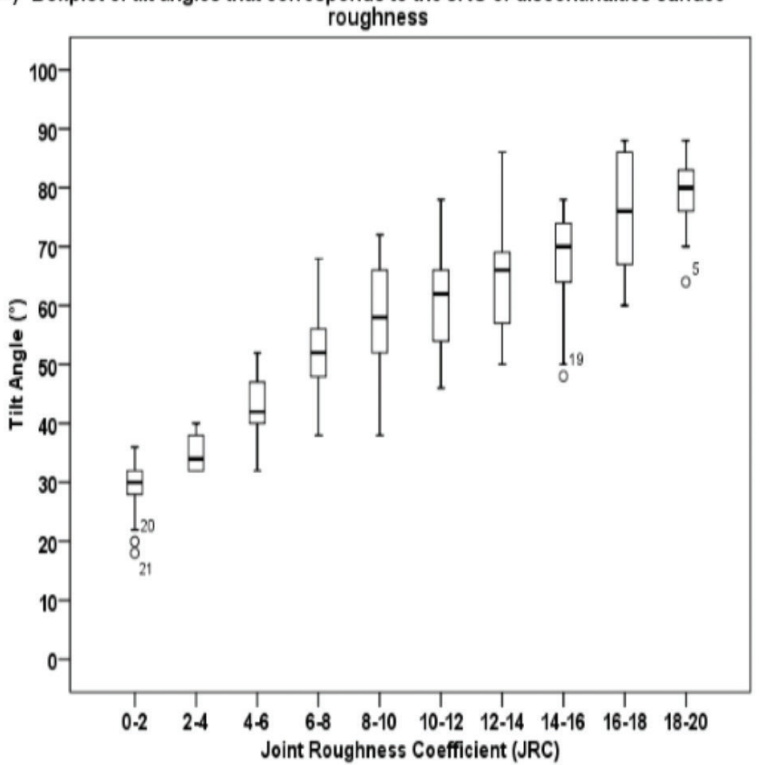

(b) Polynomial approximation between the experimental

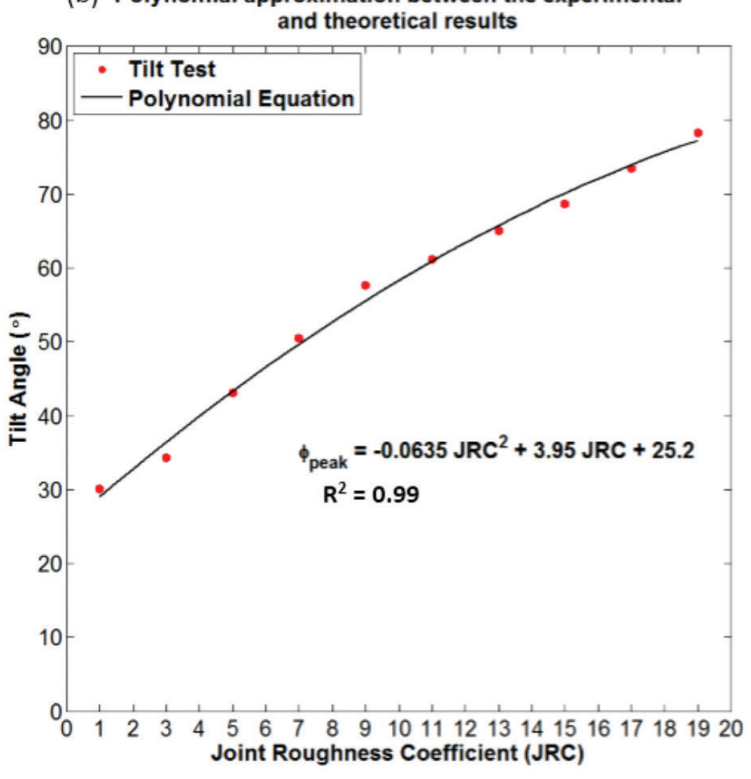

FIGURE 6. (a) Boxplots of tilt angles that corresponds to the JRC of discontinuities surface roughness, and (b) a polynomial approximation of $\phi_{\text {peak }}=-0.0635 \mathrm{JRC}^{2}+3.95 \mathrm{JRC}+25.2$ with a coefficient of determination $\left(\mathrm{R}^{2}\right)$ of $0.99 \mathrm{had}$ been established between the experimental and the theoretical results

The laboratory results were compared with theoretical results to estimate the peak friction angle by using Barton (1973) linear equation. The basic friction angle in (3) were taken from the results of tilt test. The input data for calculation of peak friction angle using Barton (1973) linear equation includes the bulk density of rock $\left(\mathrm{kg} / \mathrm{m}^{3}\right)$ and the uniaxial compressive strength (MPa) value of rock. From measurement in the laboratory, the average bulk density and uniaxial compressive strength value of limestone is $2670 \mathrm{~kg} / \mathrm{m}^{3}$ and $70 \mathrm{MPa}$, respectively. From measurement in the field, it was found that the approximate rock slope height at the study areas is $10 \mathrm{~m}$. Normal stress, $\sigma_{\mathrm{n}}$ were determined using $\sigma_{\mathrm{n}}=$ bulk density of rock slope $\times$ height of slope. Table 2 summarizes the data input of peak friction angle using Barton (1973) linear equation.

Table 3 exhibits the comparison between peak friction angles measured from tilt test with theoretical friction angles calculated from established polynomial and Barton (1973) linear equation. Table 4 exhibits the percentage of differences between peak friction angles measured from tilt test with theoretical peak friction angles calculated from proposed polynomial and Barton (1973) linear equation. It can be seen that the percentage differences between peak friction angles measured from tilt test with theoretical peak friction angles calculated from polynomial equation ranges from $-3.6 \%$ to $5.8 \%$, while the percentage differences between peak friction angles measured from tilt test with theoretical peak friction angles calculated from Barton equation ranges from $-10.7 \%$ to $8.2 \%$.

The comparisons are presented in a plot of peak friction angles versus JRC as shown in Figure 7. It can be seen that estimation of peak friction angles were made accurately by using the proposed polynomial equation when compared to estimation by using Barton (1973) linear equation.

It can be concluded that the estimation of peak friction angles were done more accurate by using the polynomial equation proposed here since the percentage difference between measured and calculated peak friction angles is less than 6\% compared to estimation from Barton (1973) linear equation where the percentage of differences is less than $11 \%$. Therefore, the proposed polynomial equation

TABLE 2. Data input for measurement of peak friction angle using Barton (1973) linear equation

\begin{tabular}{lcccc}
\hline Location & Bulk Density $\left(\mathrm{kg} / \mathrm{m}^{3}\right)$ & Height of Slope $(\mathrm{m})$ & UCS $(\mathrm{MPa})$ & Normal Stress $(\mathrm{MPa})$ \\
\hline Gua Tempurung & 2680 & 10 & 51.5 & 0.263 \\
Gua Kandu & 2653 & 10 & 81.5 & 0.260 \\
Gunung Rapat & 2662 & 10 & 69.8 & 0.261 \\
Gunung Lang & 2686 & 10 & 75.1 & 0.263 \\
Gunung Keriang & 2678 & 10 & 74.7 & 0.263 \\
Gua Damai & 2653 & 10 & 55.5 & 0.260 \\
\hline
\end{tabular}


TABLE 3. Comparison of peak friction angles measured from tilt test with theoretical peak friction angles calculated from established polynomial and Barton (1973) linear equation

\begin{tabular}{lcccccccccc}
\hline $\begin{array}{l}\text { Method / } \\
\text { JRC Midpoint }\end{array}$ & 1 & 3 & 5 & 7 & 9 & 11 & 13 & 15 & 17 & 19 \\
\hline Tilt Test $\left(^{\circ}\right)$ & 30.1 & 34.4 & 43.1 & 50.5 & 57.6 & 61.2 & 65.1 & 68.8 & 73.5 & 78.4 \\
Polynomial Equation $\left({ }^{\circ}\right)$ & 29.1 & 36.5 & 43.4 & 49.8 & 55.6 & 61.0 & 65.8 & 70.2 & 74.0 & 77.3 \\
Barton $(1973)$ Linear Equation $\left({ }^{\circ}\right)$ & 32.6 & 37.4 & 42.3 & 47.2 & 52.1 & 57.0 & 61.8 & 66.7 & 71.6 & 76.5 \\
\hline
\end{tabular}

TABLE 4. Percentage of differences between peak friction angles measured from tilt test with theoretical peak friction angles calculated from established polynomial and Barton (1973) linear equation

\begin{tabular}{lcccccccccc}
\hline $\begin{array}{l}\text { Method / } \\
\text { JRC Midpoint }\end{array}$ & 1 & 3 & 5 & 7 & 9 & 11 & 13 & 15 & 17 & 19 \\
\hline Polynomial Equation (\%) & -3.5 & 5.8 & 0.7 & -1.6 & -3.6 & -0.3 & 1.1 & 2.0 & 0.7 & -1.4 \\
Barton Equation (\%) & 7.5 & 8.2 & -1.8 & -7.1 & -10.7 & -7.4 & -5.2 & -3.1 & -2.7 & -2.5 \\
\hline
\end{tabular}

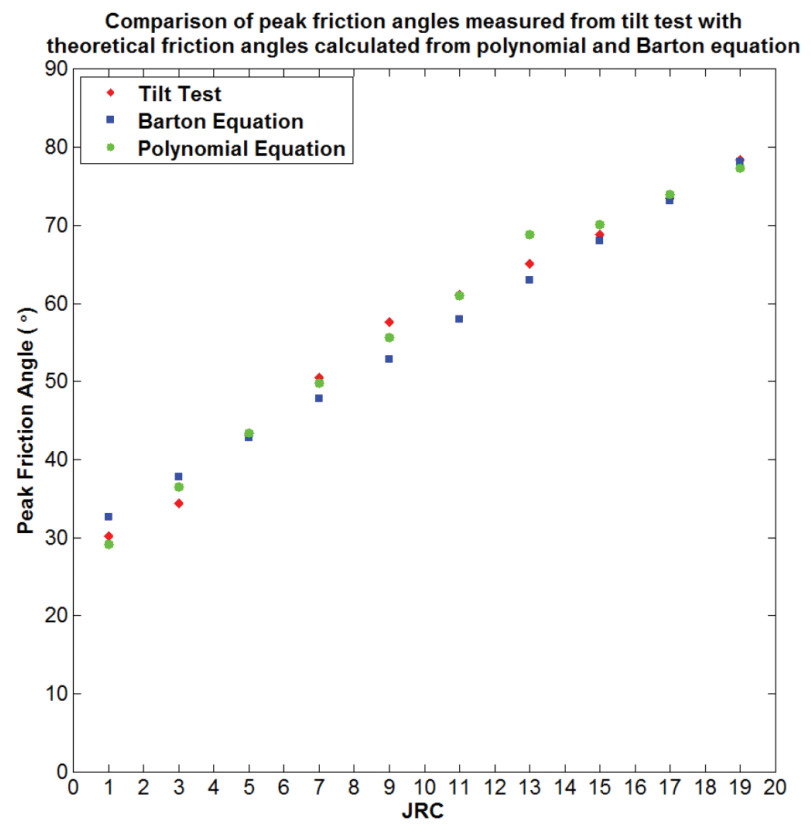

FIGURE 7. Plot of peak friction angles versus JRC showing the comparison of peak friction angles measured from tilt test with theoretical peak friction angles calculated from established polynomial and Barton (1973) linear equation

offers an acceptable and valid means of estimating the peak friction angle of discontinuity surfaces roughness of limestone from JRC measurements in the field.

\section{CONCLUSION}

A new polynomial equation has been developed in this study to estimate the values of peak friction angle of discontinuity surface from JRC measurement for limestones in Kinta Valley, Gunung Keriang and Gua Damai. The new equation is $\phi_{\text {peak }}=-0.0635 \mathrm{JRC}^{2}+3.95 \mathrm{JRC}+25.2$ with a coefficient of determination $\left(\mathrm{R}^{2}\right)$ of 0.99 . Comparison between peak friction angles values calculated from this polynomial and Barton (1973) linear equation showed that estimation of peak friction angles were determined more accurately by using the polynomial equation that has been developed. The findings emphasized the importance in estimation of peak friction angles as it offers a reliable means of computation. The strong correlation between tilt angles and JRC values shows the influence of discontinuity surface roughness on the shear strength of the discontinuity surfaces. The equation is applicable to limestone samples in Malaysia at low normal stress levels and is expected to be useful for evaluation of rock slope stability during excavation projects in civil, mining and geotechnical industry. 


\section{ACKNOWLEDGMENTS}

This publication is based on work supported by the Government of Malaysia under grant Fundamental Research Grant Scheme FRGS/1/2016/STG08/UTP/01/1 and GUP-2016-024. The authors would also like to acknowledge the support of the staff and facilities at Geology Program and Faculty of Science and Technology, Universiti Kebangsaan Malaysia.

\section{REFERENCES}

Barton, N. 1973. Review of a new shear strength criterion for rock joints. Engineering Geology 7: 287-332.

Barton, N. \& Choubey, V. 1977. The shear strength of rock joints in theory and practice. Rock Mechanics 10: 1-54.

Coulomb, C.A. 1773. Essai sur une application des regies des maximis et minimis a quelques problemes de statique relatifs a 1'architecture. Mem. pres. par div. savants. 7: 343-382.

Fecker, E. \& Rengers, N. 1971. Measurement of large scale roughness of rock planes by means of Profilograph and geological compass. Rock Fracture, Proc. of Int. Symp. Rock Mech Nancy 1: 18.

Foo, K.Y. 1990. Geology and mineral resources of the TaipingKuala Kangsar Area, Perak Darul Ridzuan. Geol. Survey Malaysia, Map Rept. 1, p. 145.

Gobbett, D.J. 1964. The lower paleozoic rocks of Kuala Lumpur, Malaysia. Federation Museum's Journal 9: 67-79.

Ghani Rafek, A., Goh, T.L. \& Hariri Arifin, M. 2012. Korelasi pekali kekasaran kekar dengan sudut geseran puncak satah ketakselanjaran batuan Syis, Semenanjung Malaysia. Sains Malaysiana 41(3): 293-297.

Ghani, R.A., Goh, T.L., Hariri, A.M. \& Baizura, Y.N. 2011. Field and laboratory-based approach for the determination of friction angle of geological discontinuities of Malaysian granites. Asean J. Sc. Technol. Dev. 28(2): 151-155.

Goh Thian Lai \& Abdul Ghani Rafek. 2012. Correlation of joint roughness coefficient (JRC) and peak friction angles of discontinuities of Malaysian Schists. Earth Science Research 1(1): 57-63.

Goh, T.L., Abdul Ghani, R., Ailie, S.S., Azimah, H. \& Lee, K.E. 2016. Use of ultrasonic velocity travel time to estimate uniaxial compressive strength of granite and schist in Malaysia. Sains Malaysiana 45(2): 185-193.

Goh, T.L., Ghani Rafek, A. \& Hariri Arifin, M. 2014a. Correlation of joint roughness coefficient with peak friction angles of discontinuity planes of granite, Peninsular Malaysia. Sains Malaysiana 43(5): 751-756.

Goh, T.L., Abdul Ghani, R., Ailie, S.S., Norbert, S. \& Lee, K.E. 2014b. Empirical correlation of uniaxial compressive strength and primary wave velocity of Malaysian granites. Electronic Journal Geotechnical Engineering 19(E): 1063-1072.

Goh, T.L., Abdul Ghani, R., Ailie, S.S., Norbert, S., Lee, K.E. \& Azimah, H. 2015a. Empirical correlation of uniaxial compressive strength and primary wave velocity of Malaysian Schists. Electronic Journal Geotechnical Engineering 20: 1801-1812.

Goh, T.L., Abdul Ghani, R., Ailie, S.S., Norbert, S., Azimah, H. \& Lee, K.E. 2015b. Correlation of ultrasonic velocity slowness with uniaxial compressive strength of schists in Malaysia. Electronic Journal Geotechnical Engineering 20: 12663-12670.
Jones, C.R. 1976. Geology and Mineral Resources of Perlis, North Kedah and the Langkawi Islands. District Memoir No.17. Geological Survey Malaysia. Kuala Lumpur: Jabatan Penyiasatan Kajibumi Malaysia.

Norbert, S., Michael, C., Mairead, d.R. \& Abdul Ghani, R. 2013. Point based assessment: Selecting the best way to represent landslide polygon as point frequency in landslide investigation. Electronic Journal Geotechnical Engineering 18(d): 775-784.

Norbert, S., Michael, C., Mairead, d.R., Abdul Ghani, R. \& Rodeano, R. 2015a. Time series assessment on landslide occurrences in an area undergoing development. Singapore Journal of Tropical Geography 36: 98-111.

Norbert, S., Muhammad Fahmi, A.G., Goh, T.L., Abdul Ghani, R., Azimah, H., Rodeano, R. \& Lee, K.E. 2015b. Assessment of rockfall potential of limestone hills in the Kinta Valley. Journal of Sustainability Science and Management 10(2): 24-34.

Norbert, S., Rodeano, R., Abdul Ghani, R., Goh, T.L., Noran, N.N.A., Kamilia, S., Nightingle, L.M., Azimah, H. \& Lee, K.E. 2016. Rock mass assessment using geological strength index (GSI) along the Ranau-Tambunan Road, Sabah, Malaysia. Research Journal of Applied Sciences, Engineering and Technology 12(1): 108-115.

Norbert, S., Rodeano, R., Nightingle, L.M., Juhari, M.A., Abdul Ghani, R. \& Goh,T.L. 2014. Lineaments and their association with landslide occurrences along the Ranau-Tambunan Road, Sabah. Electronic Journal Geotechnical Engineering 19(c): 645-656.

Patton, F.D. 1966. Multiple modes of shear failure in rock. Proc. 1st International Congress of Rock Mechanics, Lisbon 1: 509-513.

Priest, S.D. 1993. Discontinuity Analysis for Rock Engineering. London: Chapman \& Hall.

Ailie Sofyiana Serasa, Goh Thian Lai* \& Azimah Hussin Geology Program, School of Environmental and Natural Resource Sciences

Faculty of Science and Technology

Universiti Kebangsaan Malaysia

43600 UKM Bangi, Selangor Darul Ehsan

Malaysia

Ailie Sofyiana Serasa

Chemical and Petroleum Engineering Department

Faculty of Engineering, Technology and Built Environment UCSI University, 56000 Cheras, Kuala Lumpur Malaysia

Abdul Ghani Rafek

Department of Geosciences, Universiti Teknologi PETRONAS Bandar Seri Iskandar, 31750 Tronoh, Perak Darul Ridzuan Malaysia

Lee Khai Ern

Institute for Environment and Development (LESTARI)

Universiti Kebangsaan Malaysia 43600 UKM Bangi, Selangor Darul Ehsan Malaysia 
Tuan Rusli Mohamed

Jabatan Mineral dan Geosains Malaysia, Perak

Jalan Sultan Azlan Shah

31400 Ipoh, Perak Darul Ridzuan

Malaysia
*Corresponding author, email: gdsbgoh@gmail.com

Received: 1 March 2016

Accepted: 6 June 2016 